\title{
The role of interstitial (crowdion) mass-transfer for crack high-temperature healing under uniaxial loading
}

\author{
M.A.Volosyuk ${ }^{1}$, A.V.Volosyuk ${ }^{1}$, N.Ya. Rokhmanov ${ }^{2}$ \\ ${ }^{1}$ Kharkiv National Automobile and Highway University, \\ 25 Petrovskogo Str., 61002 Kharkiv, Ukraine \\ ${ }^{2}$ V. Dokuchaev Kharkiv National Agrarian University, p/o Communist, \\ 62483 Kharkiv, Ukraine
}

Received October 31, 2014

\begin{abstract}
Crack healing was experimentally studied in the samples of pure copper at the temperature $T=873 \mathrm{~K}\left(\approx 0.65 T_{m}\right)$ under conditions of uniaxial loading perpendicular to the crack bedding plane. Analysis of experimental results using the kinetic equation of the crack healing by the dislocation-diffusion mechanism has shown that under such conditions the healing process is controlled by diffusion dissolution of generated dislocation prismatic loops due both to their vacancy "evaporation" caused by the loop curvature and to absorption of interstitial atoms generated in the cross-points of dislocation lines. Under conditions of the described experiments, both possibilities have been shown to realize equally that substantially accelerates the crack healing process. The migration of interstitial atoms in crowdion configuration has been proved quite real.

Keywords: crack healing, uniaxial loading, dislocation-diffusion mechanism, interstitial atom, crowdion.
\end{abstract}

Экспериментально исследовано залечивание трещин в образцах из чистой меди при температуре $T=873 \kappa\left(\approx 0,65 T_{m}\right)$ в условиях одноосного нагружения перпендикулярно плоскости залегания трещин. Показано, что в указанных условиях процесс залечивания трещин контролируется диффузионным растворением образующихся призматических дислокационных петель как за счет их повакансионного "испарения", обусловленного кривизной петель, так и за счет поглощения межузельных атомов, образующихся в местах пересечений дислокационных линий. Показано, что в условиях проведенных экспериментов обе возможности реализуются практически в одинаковой мере, что существенно ускоряет процесс залечивания трещин. Отмечена реальность в изучаемых условиях межузельной миграции атомов в краудионной конфигурации.

Роль міжвузельного масопереносу у високотемпературному заліковуванні тріщин за умов одноосного навантаження. М.А.Волосюк, А.В.Волосюк, М.Я. Рохманов.

Експериментально досліджено заліковування тріщин у зразках з чистої міді при температурі $T=873 \mathrm{~K}\left(\approx 0,65 T_{m}\right)$ за умов одноосного навантаження перпендикулярно до площини залягання тріщин. Показано, що за вказаних умов процес заліковування тріщин контролюється дифузійним розчиненням утворених призматичних дислокаційних петель як за рахунок їхнього повакансійного "випаровування", обумовленого кривизною петель, так і за рахунок поглинання міжвузельних атомів, що утворюються в місцях перетинів дислокаційних ліній. Показано, що за умов проведених експериментів обидві можливості реалізуються практично в однаковій мірі, що істотно прискорює процес заліковування тріщин. Відмічено реальність за цих умов міжвузельної міграції атомів у краудіонній конфігурації. 


\section{Introduction}

The dislocation-diffusion mechanism of transfer processes is the object of a lot of attention due to great importance for preparation of new materials with desired structure and properties using the technologies of sintering [1], powder metallurgy [2], diffusion welding $[3,4]$, nano-technologies [5, $6]$, intense plastic deformation at higher temperature [7], densification of materials by healing the pores and cracks [8], etc.

The dislocation mechanism of crack healing under uniaxial compression without heating was studied in [9]. The crack healing by the dislocation-diffusion mechanism under high temperature $\left(600^{\circ} \mathrm{C} \approx 0.65 T_{m}\right)$ in the pure copper samples was investigated in [10]. In the description and analysis of the process in [10] it was assumed that crack generated prismatic dislocation loops of vacancy type dissolved by diffusion due to their curvature thus stimulating new loop generation and the crack healing. In the theory developed in [11], another mechanism is considered along with the abovementioned one: this is related with possible supersaturation of the lattice by point defects (in this case - by interstitial atoms) and their absorption by dislocation loops; the process also results in dissolving the loops and stimulating the healing process.

The aim of the work is studying the kinetics of crack high temperature healing in copper samples preliminary annealed for long term at high temperature for structure stabilization; investigation of healing mechanisms, and searching for a way to determine the proportion between contributions of different mechanisms into the crack healing process.

\section{Experiment, results and discussion}

The experiments were carried out on the samples of polycrystalline copper (purity $99.999 \%$ ) extensively used both as a construction material in engineering and a model material in scientific investigations.

Each sample consisted of two plates with size $(20 \times 20 \times 5) \mathrm{mm}^{2}$. The surfaces $(20 \times 20) \mathrm{mm}^{2}$ of each plate were treated thoroughly to attain flatness and parallelism. One of the plate surfaces was polished. In one of the attached plates, the flat-bottom channels of about $10^{-1} \mathrm{~cm}$ diameter and $\approx 4 \cdot 10^{-4} \mathrm{~cm}$ depth were made using the special instrument. The channels were posi-

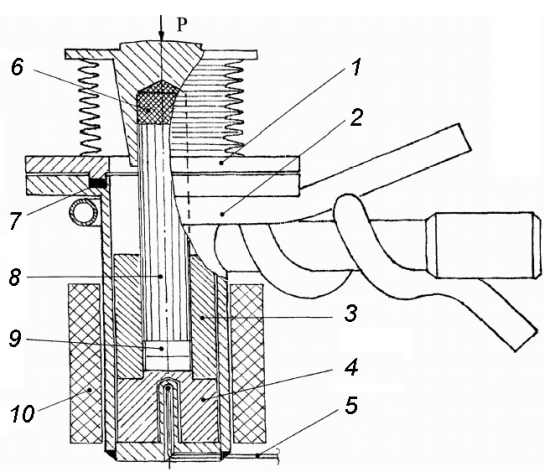

Fig. 1. The installation for annealing under loading in vacuum: 1 - cover of chamber with bellows; 2 - vacuum chamber with water cooling and choke for pump-down; 3 guiding charger of compression mold; 4 support of compression mold; 5 - thermocouple; 6 - thermo-isolating laying; $7-$ sealant laying; $8-$ punch; $9-$ sample; 10 - furnace for heating.

tioned at the distances $0.4 \mathrm{~cm}$ from each other forming a square network of 16 channels. The plates were stacked in pairs (with channels and without) and treated by diffusion welding at $T=1073 \mathrm{~K}$ in vacuum $10^{-4} \mathrm{~mm}$ $\mathrm{Hg}$ for $30 \mathrm{~min}$ in the installation for vacuum annealing under loading (shown in Fig. 1), using the loading lower Peierls' threshold. After the welding the samples were subjected to sufficiently long-term (four hours) normalizing annealing in vacuum $10^{-4} \mathrm{~mm} \mathrm{Hg}$ at $T=1073 \mathrm{~K}$ without loading in the same installation in order to stabilize the structure [12]. The initial sizes of cracks in the samples were the following: radius $a_{0}=4.5 \cdot 10^{-2} \mathrm{~cm}$ and thickness $4 \cdot 10^{-4} \mathrm{~cm}$.

Annealings under loading normal to the plane of crack bedding were carried out in vacuum of the order of $10^{-4} \mathrm{~mm} \mathrm{Hg}$ in the same installation (Fig. 1). The load was applied after vacuuming the system and achieving the required temperature. After annealings, the crack sizes were studied using optic microscope MIM-10 by commonly used metallographic methods by the fractography pictures obtained in the plane of a polished sample and from the samples polished perpendicular to the crack bedding plane.

The results were averaged by 16 cracks of each sample. The measurement results are shown in Fig. 2.

The equation for kinetic of crack healing by dislocation-diffusion mechanism is given by [10]: 


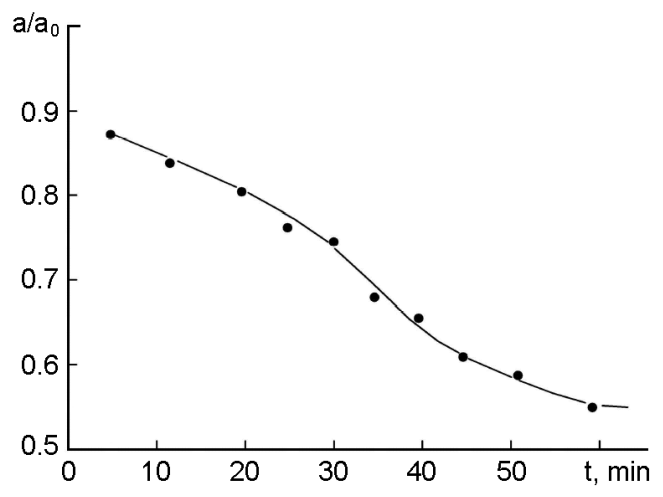

Fig. 2. Dependence of crack relative size $\left(a / a_{0}\right)$ on the time of holding under load $t$ $\left(\sigma \approx 5 \cdot 10^{6} \mathrm{~N} / \mathrm{m}^{2}\right.$ is external load stress).

$$
\begin{gathered}
1-\left(\frac{a}{a_{0}^{\prime}}\right)^{2}=\frac{2}{\left(a_{0}^{\prime}\right)^{2}} \frac{\pi a_{0}^{3 / 2} \sigma^{3}}{c^{3 / 2} \sigma_{p}^{2}} \times \\
\times\left(\frac{D \omega}{k T}+\frac{4 \pi(1-v) R_{l} D_{V} \Delta C_{i}}{G b \ln \left(8 R_{l} / b\right)}\right)\left(t-t_{0}\right),
\end{gathered}
$$

where $t, t_{0}$ are, respectively, the running time and the time of a quasi-stationary dislocation ensemble formation in the crack vertex after loading (in our case $t_{0}=5 \mathrm{~min}$ was taken); $a_{0}, a, a_{0}^{\prime}$ are radii of the crack, respectively: initial (before loading), running, and the radius to time $t_{0}\left(a_{0}=4.5 \cdot 10^{-4} \mathrm{~m}\right.$, $\left.a_{0}{ }^{\prime}=0.88 a_{0}\right) ; c=4 \cdot 10^{-6} \mathrm{~m}$ is the crack thickness; $v=0.3$ is Poisson coefficient; $b \approx 3 \cdot 10^{-10} \mathrm{~m}$ is Burgers vector; $\omega=$ $1.18 \cdot 10^{-29} \mathrm{~m}^{3}$ is atomic volume; $k=$ $1.38 \cdot 10^{-23} \mathrm{~J} / \mathrm{K}$ is Boltzmann constant; $T$ is experiment temperature $(T=873 \mathrm{~K}) ; R_{l}$ is radius of a generated prismatic dislocation loop (taken as $R_{l} \approx c / 2=2 \cdot 10^{-6} \mathrm{~m}$ ); $G=$ $4.15 \cdot 10^{10} \mathrm{~N} / \mathrm{m}^{2}$ is shear modulus in copper; $\sigma \approx 5 \cdot 10^{6} \mathrm{~N} / \mathrm{m}^{2}$ is the stress from external load; $D$ is self-diffusion coefficient for atoms in copper (at $T=873 \mathrm{~K}, D=3.1 \cdot 10^{-17} \mathrm{~m}^{2} / \mathrm{s}$ ); $D=D_{V} C_{V}^{0} ; D_{V}$ is vacancy diffusion coefficient; $C_{V}^{0}$ is vacancy equilibrium concentration at given temperature $T ; \Delta C_{i}=C_{i}-C_{i}^{0}$ is supersaturation of lattice by interstitial atoms; $C_{i}, C_{i}^{0}$ are respectively, the real and the equilibrium concentrations of interstitials at temperature $T ; \sigma_{p}$ is Peierls' threshold.

The first term in (1) characterizes the flux of the loop dissolution due to curvature, the second - due to supersaturation

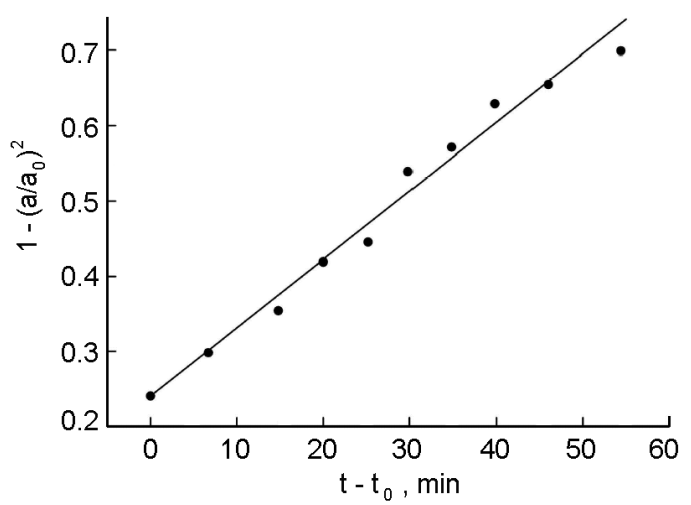

Fig. 3. Dependence $\left\{1-\left(a / a_{0}^{\prime}\right)^{2}\right\}$ on $\left(t-t_{0}\right)$. $\left(\sigma \approx 5 \cdot 10^{6} \mathrm{~N} / \mathrm{m}^{2}\right)$.

of lattice by interstitial atoms. The equation (1) can be written in more compact and convenient form:

$$
1-\left(\frac{a}{a_{0}^{\prime}}\right)^{2}=\left(\alpha \gamma+\alpha \beta D_{V} \Delta C_{i}\right) \frac{\left(t-t_{0}\right)}{\sigma_{p}^{2}},
$$

where

$$
\begin{gathered}
\alpha=\frac{2 \pi a_{0}^{3 / 2} \sigma^{3}}{\left(a_{0}^{\prime}\right)^{2} c^{3 / 2}} \\
\beta=\frac{4 \pi(1-v) R_{l}}{G b \ln \left(8 R_{l} / b\right)}, \quad \gamma=\frac{D \omega}{k T} .
\end{gathered}
$$

The dependence $\left\{1-\left(a / a_{0}^{\prime}\right)^{2}\right\}$ versus $\left(t-t_{0}\right)$ constructed by the data obtained is found to be linear indeed (Fig. 3), but two values $\sigma_{p}$ and $\Delta C_{i}$ in (2) are unknown in principle, and it is impossible to determine these from the single equation. If the contribution of interstitials migration is considered absent, i.e. $\alpha \beta D_{V} \Delta C_{i}=0$, then taking into account the angle coefficient of the curve (Fig. 3) we obtain the value $\sigma_{p} \approx 0.4 \cdot 10^{5} \mathrm{~N} / \mathrm{m}^{2}$ from (2). This value $\sigma_{p}$ is probable for well annealed soft materials $[11,12]$, although it seems to be somewhat understated.

During the crack high-temperature healing, there take place intense plastic deformation at crack vertexes, dislocation intersection, and generation of new point defects as a result of dislocation movement [17]. At that, supersaturation of the lattice by interstitial atoms may occur; this will promote additional dissolution of vacancy loops and advancement of crack healing. The value $\sigma_{p}$, as it follows from (2), if found to be higher than in the case when $\alpha \beta D_{V} \Delta C_{i}=0$. Indeed, if $\alpha \beta D_{V} \Delta C_{i}>0$, the expression $(\alpha \gamma+$ 
$\alpha \beta D_{V} \Delta C_{i}$ ) becomes higher, and $\sigma_{p}$ following from (2) and the data of Fig. 3 increases as well.

Let us suppose for certainty, that the contributions into dissolution of dislocation loops due to their curvature and due lattice supersaturation by interstitials are similar. The value $\left(\alpha \gamma+\alpha \beta D_{V} \Delta C_{i}\right)$ in (2) becomes twice as higher, and $\sigma_{p}$ increases by the factor $\sqrt{2}$, so becomes more real and close to values obtained for other cases like this. Thus, the value $\sigma_{p}$ is found to be a parameter allowing in principle to define the role of each of possible mechanisms of dislocation loop dissolution more exactly. If $\sigma_{p}$ is known promptly from independent sources, from the condition $\alpha \gamma=\alpha \beta D_{V} \Delta C_{i}$ in (2) the evaluation of supersaturation $\Delta C_{i}$ can be obtained.

Let us discuss the reality of the situation of equality $\alpha \gamma=\alpha \beta D_{V} \Delta C_{i}$ in (2) and evaluate the necessary supersaturation $\Delta C_{i}$ by interstitials. Taking into account that diffusion activation energy of vacancies is of the order of activation energy for their generation [12], i.e. $\sim 1 \mathrm{eV}$, we obtain $D_{V} \approx 1.7 \cdot 10^{-6} \mathrm{~m}^{2} / \mathrm{s}$, then $\Delta C_{i} \approx 6.2 \cdot 10^{-13}$. In order to affirm that the role of atomic interstitial migration in dislocation-diffusion mechanism of crack healing is real, it is necessary to show the reality of the evaluation obtained $\Delta C_{i} \approx 6.2 \cdot 10^{-13}$ under conditions of our experiments.

Thermodynamic equilibrium concentration of interstitial atoms in metals with FCC lattice is very low. This is connected with high energy of interstitial atom generation $U_{f i}$, that is caused by high packing density of atoms in FCC lattices resulting in high mechanical stress during embedding the atom into interstitial. In literature, substantially different data on $U_{f i}$ value from $3 \mathrm{eV}$ to $6 \mathrm{eV}$ are given [12-14]. Such uncertainty is characteristic just for metals of transition group, namely, copper, silver and gold. During reciprocal movement of atoms of these metals, complex interactions occur between electrons of unoccupied external $f$, $d$, etc. atomic shells [14]. As the result of the interactions depends on a lot of local parameters in the metal, the value $U_{f i}$ is unstable and difficult to predict.

The equilibrium concentration of interstitial atoms at temperature $T$ is determined by the relation [12]:

$$
C_{i}^{0}=A \exp \left(-\frac{U_{f i}}{k T}\right) \text {. }
$$

For the case of defect small concentration: $A \approx 1$ [12]. Let us take the energy of an interstitial atom in copper as $U_{f i}=5 \mathrm{eV}$; the value is practically coincides with crowdion generation energy in copper according to calculations $[15,16]$. Substituting the incoming values in (3) at $T=873 \mathrm{~K}$ and $U_{f i}=5 \mathrm{eV}$ we obtain $C_{i}^{0}=1.5 \cdot 10^{-29}$ (at $U_{f i}=3 \mathrm{eV}$ : $\left.C_{i}^{0}=5 \cdot 10^{-18}\right)$. As $\Delta C_{i}=C_{i}-C_{i}^{0}$, and $C_{i}^{0}<<\Delta C_{i}$, in order to obtain the expected contribution of interstitial atomic migration into dissolution of dislocation loops, the condition $\Delta C_{i} \approx C_{i} \approx 6.2 \cdot 10^{-13}$ should be fulfilled, that exceeds the possible concentration by several orders of value in the framework of the model of interstitial thermo-fluctuation generation.

However, it should be taken into account that in our case the situation is substantially different: local plastic deformation takes place, and interstitial atoms are generated not only spontaneously due to thermal fluctuations, but also under micro-plastic deformation where the steps lying out of the moving dislocation slip planes are formed at intersecting dislocations [17]. Being locks for moving dislocations these steps can only climb by diffusion, generate interstitials or vacancies, and release the dislocation segment to take part in following deformation. At that the transition of the hanged dislocation segment into the next Peierls valley takes place - an elemental act of plastic deformation for which external force work is spent. Such approach to analyzing the movement of dislocation with steps indicates the necessary to take into account the specific mechanism of their generation when determining the point defect concentration during plastic deformation. In this case during generation of an interstitial atom, external forces accomplish work $A=\sigma b l a$ [17] on transference of a dislocation segment with $l$ length under external stress $\sigma$ by $a$ distance between adjacent Peierls valleys. Thus, for concentration of interstitial atoms under plastic deformation we obtain an estimation expression [17]:

$$
C_{i}=B \exp \left(-\frac{U_{f i}-\sigma b l a}{k T}\right)
$$

In this equation, all the values are defined except for the length of a dislocation segment $l$. Therefore, using (4) we estimate the value $l$ and its reality under conditions of our experiments. Taking into account $B \approx 1$ 
[17], $C_{i} \approx 6.2 \cdot 10^{-13}, \quad \sigma \approx 5 \cdot 10^{6} \mathrm{~N} / \mathrm{m}^{2}$ and other incoming values mentioned above we obtain:

$$
l \approx \frac{U_{f i}+k T \ln C_{i}}{\sigma b a} \approx(4.6 \div 4.8) \cdot 10^{-7} \mathrm{~m}
$$

The obtained $l$ correlates with data from [17], therefore, the assumption on the possible participation of interstitial mass-transfer in vacancy type prismatic dislocation loops dissolution promoting the new loops generation and subsequent healing the crack is justified.

As well it is necessary to note the following. As the mobility of interstitials is significantly higher than vacancy mobility, it appears that in the beginning stage of deformation (until the dislocation density does not exceed $\left.\rho>\left(10^{10} \div 10^{11}\right) \mathrm{cm}^{-2}\right)$, the number of steps generating interstitials is higher by a factor 1.5 than the number of steps generating vacancies [17] — the fact resulting in supersaturation of the lattice by interstitial atoms.

Possible mechanisms of interstitial migration in the crystalline lattice (except for vacancy one) were considered in [12]. An interstitial atom can jump into neighboring interstitial through valley between atoms. This is connected with significant shifting the pulling out atoms, high elastic stress, and hence, with high energy barrier for such jump. Another mechanism is possible: being among other atoms forming a closepacked row, an interstitial atom push out a neighboring atom into an interstitial, thus occupying its position; such "token passing" of the interstitial atom (sometimes called "token migration" [13]) in the form of socalled crowdion configuration $[12,15]$ goes on further. The energy $U_{d c r}$ need for such movement is low in the case when the intermediate position of a pair of atoms in the midpoint (in the lattice site) forms a stable "semi-interstitial" position [12]. Such configuration is called also an interstitial pair. The possibility of such mechanism for plastic deformation due to formation of a local atomic densification in the close-packed row and its movement was mentioned long ago in works by T.Kantorova and J.Frenkel (1938). Theoretic evaluations and experimental data $[12,13]$ on the value of activation energy for interstitial migration $U_{d i}$ in crowdion configuration indicate it is in the range $U_{d i} \approx 0.05 \div 0.2 \mathrm{eV}$ for copper, that signifies high mobility of interstitial atoms (crowdions).
A great role of the crowdion transfer is often discussed under conditions of local, strongly inhomogeneous deformations (pulse or shock loading, etc. [18-20]). In a number of works, for example [21-23], the important role of crowdions moving in dynamic regime with supersonic speeds was shown by the method of molecular dynamics. This matter is principally important for our case, because it is the high mobility of interstitial atoms that determines their preferential generation at the dislocation crosspoints and supersaturation [17], so, active participation in the crack healing.

Consequently, during the crack healing, the supersaturation of the lattice by interstitial atoms takes place and these are very mobile ( $U_{d i}$ is small), so, the contribution of the interstitial atom flux into loops dissolution is inevitable. As our experiments and estimations show, this contribution is practically of the same order that the flux of the loops dissolution caused by their curvature. Hence, it would be quite logically to assume the mechanism of their migration be crowdion on account of crowdions high mobility.

\section{Conclusions}

The experiments have been carried out on studying the kinetics of crack healing at high temperature $T=873 \mathrm{~K}\left(\approx 0.65 T_{m}\right)$ under conditions of uniaxial loading the copper samples having cracks. It was shown that under conditions of developing local plasticity, at vertexes of cracks being healed, the vacancy prismatic loops form; these are dissolved by diffusion not only as a result of their curvature, but also due to absorption of interstitial atoms generated at the points of dislocation line intersections. The attention has been paid to the possibility of crowdion participation as the factor promoting accelerated interstitial transfer. Analysis of experimental results and evaluations has shown that the contribution of interstitial (crowdion) mass-transfer is of the same order that the contribution of diffusion mechanism caused by curvature of dislocation loops.

Authors thanks Prof.V.Kononenko for an idea, advices, and discussion of results in details.

\section{References}

1. Scintillation Materials: Preparation, Properties, Applications. A Book of Articles ed. by B.Grinev, Institute for Single-Crystals, Kharkov (2007) [in Russian]. 
2. V.V.Skorokhod, S.M.Solonin, Physical and Metallurgical Bases of Powder Sintering, Metallurgy, Moscow (1984) [in Russian].

3. A.V.Lyushinskiy, Diffusion Welding of Different Materials, Akademia, Moscow (2006) [in Russian].

4. V.I.Makhnenko, V.V.Kvasnitskiy, Automat. Welding, 8, 11 (2009).

5. V.N.Betekhtin, A.G.Kadomtsev, FTT, 47, 801 (2005).

6. Yu.I.Boyko, T.G.Garbovitskaya, Yu.V.Malyukin et al., Bull. Kharkiv National University named by V.Karazin, 914, 60 (2010).

7. M.I.Lerner, G.G.Savelyev, N.V.Svarovskaya, A.I.Galanov, Izvestiya Tomskogo Politekhnicheskogo Universiteta, 309, 69 (2006).

8. A.M.Glezer, L.S.Metlov, FTT, 52, 1090 (2010).

9. Yu.I.Boyko, M.A.Volosyuk, Bull. Kharkiv National University named by V.N.Karazin, 1020, 42 (2012).

10. Yu.I.Boyko, M.A.Volosyuk, V.G.Kononenko, Functional Materials, 19, 245 (2012).

11. A.M.Kosevich, E.K.Saralidze, V.V.Slyozov, $F T T, 6,3383$ (1964).

12. J.Fridel, Dislocations, Pergamon Press, Oxford-London-Edinburgh-New York-ParisFrankfurt (1964).
13. A.Damask, J.Deans, Point Defects in Metals, Mir, Moscow (1966) [in Russian].

14. B.S.Bokstein, S.Z.Bokstein, A.A.Zhukhovitskiy, Thermodynamics and Kinetics of Diffusion in Solids, Metallurgiya, Moscow (1974) [in Russian].

15. V.D.Natsik, S.N.Smirnov, E.I.Nazarenko, $F N T, 27,1295$ (2001)

16. V.D.Natsik, E.I.Nazarenko, FNT, 26, 283 (2000).

17. J.Hirth, J.Lothe, Theory of Dislocations, McGraw-Hill, New York (1968).

18. Yu.I.Golovin, A.I.Tyurin, FTT, 42, 1818 (2000).

19. Yu.I.Boyko, M.A.Volosyuk, V.G.Kononenko, Functional Materials, 19, 289 (2012).

20. M.A.Volosyuk, Problems of Atomic Scie. Technol., 4, 55 (2014).

21. N.H.March, D.I.Pushkarov, J. Phys. Chem. Solids, 57, 139 (1996).

22. P.M.Derlet, D.Nguyen-Manh, S.L.Dudarev, Phys.Rev. B: Condens. Matter and Material. Phys., 76, 054107 (2007).

23. A.M.Iskandarov, N.N.Medvedev, P.V.Zakharov, S.V.Dmitriev, Comput. Materi. Science, 47, 429 (2009). 